\title{
PAULO LINS: O NEGRO QUE CONSEGUIU ROMPER OS CÓDIGOS, AS TRADIÇÕES QUE ASSEGURAM 0 CAMPO LITERÁRIO
}

\author{
PAULO LINS: THE NEGRO WHO BROKE THE \\ CODE, THE TRADITIONS WHICH ASSURE \\ THE LITERARY FIELD
}

\author{
Eliane Aparecida Dutra' \\ [https://orcid.org/0000-0002-7454-7784] \\ DOI: 10.30612/raido.v15i37.14628
}

RESUMO: Paulo Lins ao apresentar pautas da vida popular, a violência e a miséria nas grandes cidades brasileiras em sua obra literária Cidade de Deus, lançada em 1997, saiu do anonimato. Seu romance o colocou entre os melhores escritores brasileiros. Cidade de Deus é, certamente, uma obra incomum no universo da literatura brasileira, ganhou atençăo de leitores, dividiu opiniōes entre jornalistas, demais intelectuais e artistas tanto pela riqueza da abordagem da vida dos moradores, entre as décadas de 1960 e 1980, em meio ao desenvolvimento da violência, no Conjunto Habitacional Cidade de Deus, como por ter sido escrita por um negro, morador do universo representado, a favela. Desse modo, o objetivo aqui é apresentar a fortuna crítica de Cidade de Deus e refletir sobre a construçăo literária no Brasil, a fim de verificar quem săo e onde devem estar os que almejam ter acesso ao campo literário. O interesse em identificar e analisar perfil do escritor brasileiro é devido observamos que as discussôes levantadas contra o romance, parecem estar relacionadas à questăo da origem e do status social do escritor. As análises desenvolvidas estăo ancoradas nos estudos de Michel Foucault (2004), Pierre Bourdieu (2013) e Regina Dalcastagnè (2017).

Palavras-chave: Literatura; Perfil do escritor brasileiro; Negros.

ABSTRACT: Paulo Lins, in presenting agendas of popular life, violence and misery in large Brazilian cities in his literary work Cidade de Deus, launched in 1997, took him out of anonymity. His novel placed him among the best Brazilian writers. Cidade de Deus is certainly an unusual work in the universe of Brazilian literature, gained the attention of readers, divided opinions among journalists, other intellectuals, and artists both for the richness of the approach to the life of residents, between the decades of 1960 and 1980, amid of the development of violence, in the Cidade de Deus housing complex, as for having been written by a black, resident of the universe represented, the favela. Thus, the goal here is to present the critical fortune of Cidade de Deus and to reflect on literary construction in Brazil, in order to verify to who they are and where they should

1 Doutoranda em Literatura pela Universidade Federal de Santa Catarina (UFSC). Linha de Pesquisa: Subjetividade, Memória e História. Mestre em Literatura, linha de pesquisa: Teoria Literária (UFSC). Especialista em Docência no Ensino Superior (PUCPR). 
be those who want to have access to the literary field. The interesting in identifying and analyzing the profile of the Brazilian writer is due we observe that the discussions raised against novel seem to be related to the question of the origin and social status of the writer. The analyses developed are anchored in the studies of Michel Foucault (2004), Pierre Bourdieu (2013) and Dalcastagnè (2017).

Keywords: Literature; Profile of the Brazilian writer; Black.

\section{INTRODUÇÃO}

Ao refletir sobre literatura brasileira e sua relaçăo com a sociedade contemporânea, nos deparamos com este fenômeno que é Cidade de Deus, de Paulo Lins, publicado em 1997 pela Editora Companhia das Letras. A obra pioneira, de Lins, apresenta um painel das transformaçóes sociais pelas quais passou o Conjunto Habitacional Cidade de Deus, situado na Zona Oeste da cidade do Rio de Janeiro: da pequena criminalidade, dos anos 1960 aos anos 1980, à violência generalizada e domínio do tráfico de drogas, na década de 1990.

O romance está muito ligado ao real, de forma que é difícil analisá-lo sem olhar a cidade real, os habitantes reais. Desse modo, qualquer estudo que se faça terá que considerar que o romance está se referindo a uma comunidade que de fato existe e que está localizada em uma cidade turística, eleita como uma das mais belas de nosso país. Ademais, ainda que a representaçâo da violência, dos pobres e marginalizados já tenha povoado muitas de nossas obras literárias e que tenha sido tema fértil para muitos de nossos autores, é pertinente observar que o tema presente no livro de Lins apresenta um diferencial. Mesmo que se trate de uma produçấo ficcional ele reivindica uma autenticidade testemunhal, uma vez que o autor foi morador do mesmo espaço de exclusấo que narra e que tenha convivido com as consequências da guerra implantada pelos agentes do tráfico de drogas no conjunto habitacional.

Desde seu lançamento, a obra literária Cidade de Deus se afirmou como marco, seu autor, Paulo Lins, saiu do anonimato, obteve reconhecimento dentro do campo literário, conseguiu romper os códigos, as tradiçōes que asseguram o campo literário. Assim sendo, o "silêncio dos marginalizados é coberto por vozes que se sobrepōem a ele, vozes que buscam falar em nome deles, mas também, por vezes, é quebrado pela produçăo literária de seus próprios integrantes" (DALCASTAGNE, 2008, p. 78, grifos da autora). Contudo, o autor causou discussôes sobre a sua legitimidade, por ter como autor um negro, morador do universo representado, a favela. Partindo dessas questôes, o fato de Cidade de Deus náo ter sido escrito sob perspectivas de uma classe social que se encontra distante do objeto representado chega o momento de dizer que a análise aqui empreendida é refletir sobre o romance de Lins e a construçâo literária no Brasil, a fim de verificar quem săo e onde devem estar os que ambicionam ter acesso ao campo literário. A busca pela discussâo sobre o perfil do escritor brasileiro faz-se necessária, devido ao fato de percebermos que as críticas, levantadas contra o romance de Lins, parecem estar relacionadas à questăo da sua origem. Quanto ao referencial teórico, na área literária, a investigaçăo se apoia em Regina Dalcastagnè (2017), na área histórica social, no pensamento dos dois clássicos contemporâneos das Ciências Sociais Michel Foucault (2004) e Pierre Bourdieu (2013) e outros que aparecem no decorrer deste percurso. 


\section{A FORTUNA CRÍTICA DE CIDADE DE DEUS}

Escrito em terceira pessoa com estilo inovador e linguagem direta, o livro de Paulo Lins consegue prender o leitor ao longo de suas páginas e dezenas de personagens, reunidos por denominaçôes mais gerais como: otários, malandros, vagabundos, trabalhadores, bandidos, viciados, considerados e cocotas, os quais transitam no mundo do crime ou do năo crime.

No decorrer da leitura da obra, deparamo-nos com homicídios, estupro, infanticídios, adultério. 0 best-seller tem mais de 250 personagens, sendo chamados por apelidos e vários fios narrativos intercalados. A história contada é a desordem causada pela violência que ganha proporçôes e forma no romance de Lins.

Narrado de forma crua e objetiva, Cidade de Deus nâo permite a contemplaçâo, mal acaba a narraçăo de um contexto chocante logo o leitor se depara com outro. Os testemunhos das memórias alheias sâo explorados por Lins de maneira muito objetiva, usando o inusitado como ferramenta na denúncia que se revela sua meta. Certamente, com algumas amputaçóes em seus relatos, pois, como diz o autor, a realidade năo cabe na literatura: "[...] você náo pode pegar a realidade e transformar em literatura, senáo vira documento, vira reportagem" (LINS, 2003, sem paginaçấo).

O autor de Cidade de Deus, Paulo Lins, nasceu no Rio de Janeiro, em 1958; é filho de um casal misto, uma vez que a măe é negra, descendente de africano, e o pai é branco, descendente de português do Porto ${ }^{2}$. Junto com os pais e quatro irmáos, mudou-se para o Conjunto Habitacional Cidade de Deus, aos sete anos de idade, onde morou por 30 anos. Aos 18 anos, foi fuzileiro naval. Trabalhou como garçom, motorista e feirante. Em 1982, ingressou no curso de Letras da Universidade Federal do Rio de Janeiro (UFRJ); em entrevista concedida à Anabela Mota Ribeiro, em 2003, ressaltou o escritor que, entre 120 mil moradores da Cidade de Deus, foi o primeiro a ingressar na universidade.

Lins iniciou sua escrita fazendo samba-enredo e poesia, publicou o primeiro livro de poesia em 1986, Sobre o sol3, mas foi com a escrita do livro Cidade de Deus que saiu do anonimato e adquiriu reconhecimento nas esferas literárias. Dedicou-se ao magistério e à pesquisa, trabalhou como assistente de pesquisa durante oito anos com a renomada antropóloga Alba Zaluar, cujo estudo de doutoramento se dedicava à criminalidade em Cidade de Deus. Por conta da criaçáo de letras musicais, Lins teve contato direto com os moradores, o que facilitou o desenvolvimento da pesquisa de campo coordenada por Zaluar. Além das pesquisas que Lins realizava na comunidade, também se dedicava a investigar os presos das penitenciárias Lemos Brito e Frei Caneca, ambas no Rio de Janeiro. No decorrer do desenvolvimento do trabalho como recrutador, durante suas pesquisas de campo, foi motivado pela antropóloga a escrever o romance Cidade de Deus, o que levou, aproximadamente, 10 anos, até o lançamento da primeira versăo do livro, em 1997.

2 Ressaltou ao ser entrevistado pela jornalista, Anabela Mota Ribeiro, em 2003. Anabelamotaribeiro. pt/Paulo-lins-a-pretexto-de cidade-de-deus-181225. Publicado originalmente no DNA do Diário de Notícias em 2003. Acesso em: 20 nov. 2019.

3 Em 1986 Lins era integrante do grupo Cooperativa de Poetas, onde publicou seu primeiro livro de poesia: Sobre o sol (UFR, 1986). 
O romance apresenta a violência nas grandes cidades brasileiras; retrata locais năo valorizados socialmente, como as periferias, as favelas e os subúrbios, termos utilizados para se referirem a lugares onde vivem seres humanos excluídos, nem sempre alcançados pelo olhar da sociedade em geral, embora, segundo Alba Zaluar (2000, p. 12):

Nossa fértil imaginaçáo o faça, desde logo, antro de banditismo, violência, sujeira, imoralidade, promiscuidade, etc. Duplamente excluídos por serem "outros" e por serem "incultos" e perigosos, os pobres urbanos vivem, neste olhar etnocêntrico e homogeneizador, o avesso da civilizaçăo.

A obra se destaca, também, por ter sido escrita por alguém que mora no universo retratado, de modo que podemos situar ou năo, conforme afirma Tânia Pellegrini, "[...] como sendo a encarnaçấo da voz da periferia [...]" (2005, p. 133, grifos da autora). Cidade de Deus é, certamente, uma obra incomum no universo da literatura brasileira, assim, exige novos modelos de análise, devido à riqueza de informaçóes a que se propōe a narrativa, como por exemplo, o fato de năo ser escrita sob perspectivas de uma classe social que se encontra distante do objeto representado.

O romance expóe diversas questôes da cena social brasileira, relata a realidade das grandes cidades, em seu processo estrutural, social e cultural, em suas formas complexas e diversificadas, nas quais o embate entre as diferentes classes sociais e suas consequências é notado constantemente. Para o crítico Roberto Schwarz, em seu livro Sequências Brasileiras (1999), Lins conseguiu descrever muito bem o desenvolvimento estrutural, o tráfico de drogas, a violência, tendo em vista que a obra literária está distante de ser mais uma literatura comercial; assim, os dados levantados e levados à ficcionalizaçáo constituem um olhar de quem era o objeto do estudo. Por meio da ficçấo, Paulo Lins reproduz as experiências vividas na comunidade, apresentando um lugar deteriorado, onde imperam entre as pessoas tanto a violência física quanto a moral.

Cidade de Deus está dividido em três capítulos, sendo que cada um é intitulado com o nome de um personagem - "A história de Cabeleira", "A história de Bené" e "A história de Zé Pequeno" -, mas o livro năo aborda apenas a história desses três personagens. A cada parte do livro narrado, acompanhamos o desenvolvimento dos espaços tranquilos do subúrbio sendo ocupados por famílias desabrigadas, removidas quase sempre à força, com o intuito de isolá-las das classes privilegiadas economicamente, além de promover o desenvolvimento estrutural e econômico da cidade maravilhosa, uma espécie de apartheid social.

Segundo Schwarz (1999), no romance de Lins, podemos verificar as características da vida popular brasileira: há a representaçăo de todos os tipos de violência, o que traz como consequência a desordem e o caos. 0 crítico também admite que as condiçôes precárias de vida às quais os personagens estâo submetidos resultam em "uma espécie de realidade irrecorrível, uma objetividade absurda, decorrência do acossamento, que deixam o juízo moral sem cháo. Dito isso, estamos longe do exotismo ou do sadismo da literatura comercial de assunto semelhante" (p. 167).

Tânia Pellegrini (2008), ao contrário, alega que há, em Cidade de Deus, certa ambiguidade do realismo, pois, ao mesmo tempo em que a obra pretende denunciar 
e protestar, cai na aceitaçáo e na cumplicidade "[...] aproximando-se do sadismo e do exotismo [...]" (p. 42) que o crítico Schwarz rejeita, mas que săo questóes presentes no texto. A autora assevera ainda que, se a intençăo de Lins era representar a realidade na qual vivem muitos brasileiros em favelas, ele năo atingiu seu objetivo. No entanto, Pellegrini adverte que a obra de Lins abriu "[...] uma fresta para um mundo paralelo e sempre propositalmente ignorado, o qual, para o leitor de classe média, a imensa maioria no Brasil, além de produzir uma atraçâo inescapável, desperta mais uma vez o terror e a piedade ancestrais" (2008, p. 42).

O livro de Lins dividiu opiniōes também entre jornalistas, demais intelectuais e artistas. Obteve reconhecimento dentro do campo literário, no entanto, causou discussóes sobre a sua legitimidade, devido ao fato, de ter sido escrito por alguém que pertencia ao universo representado, a favela. A imprensa, avalia Eduardo de Assis Duarte em seu artigo “Entre Sertāo e Subúrbio: Guimarăes Rosa e Paulo Lins (2001), deteve-se mais nas cenas violentas:

[...] o acúmulo de momentos brutais e da passagem pouco sutil entre o lirismo presente nas recordaçóes de infância dos bandidos que povoam o livro e as cenas de violência e grotesco que muitas vezes protagonizam. Apontou-se ainda a pouca densidade psicológica dos personagens ou mesmo certa semelhança com esquemas oriundos da narrativa trivial consagrada pela mídia (p. 120).

Duarte, em oposiçăo às críticas ressaltadas pela imprensa, argumenta que há equívocos, pois, a obra de Lins năo é uma produçăo midiática qualquer: "[...] ou uma espécie de Mário Puzzo. Cidade de Deus năo busca reescrever O poderoso chefáo [...]" (2001, p. 120). Dessa forma, o autor ainda reflete que, embora sejam contadas muitas histórias em que a violência é protagonista, Lins năo se limita ao "rosário de crimes" (idem). Assim, mesmo que a matéria central do romance seja a disputa entre quadrilhas pelo domínio do tráfico de drogas, existe, em Cidade de Deus, também a representaçâo dos dramas individuais dos personagens e que săo:

\begin{abstract}
[...] expostos desde a origem e narrados numa perspectiva interna e de classe. [...] esse outro olhar faz com que o crime surja náo como apanágio dos pobres, mas como resultado de um sistema violento em sua própria constituiçăo. 0 grande número de personagens e destinos que se cruzam no decorrer da açăo reforça o sentido dessa violência sistêmica disseminada e atualizada nas trajetórias individuais (DUARTE, 2001, p. 120).
\end{abstract}

De acordo com a incentivadora da construçăo da obra literária, Cidade de Deus, Alba Zaluar, o livro é o primeiro romance etnográfico brasileiro que năo trata de memórias da infância do escritor decorrentes de sua biografia. “É o resultado de uma pesquisa etnográfica que năo tenta convencer o leitor de que a sua narrativa é do plano real, do realmente acontecido" (LINS, 1997, orelha interna) ${ }^{4}$.

Já em entrevista a Antônio Góis, do jornal Folha de Sâo Paulo, em 2004, falando sobre o tema criminalidade, Zaluar expressa seu desapontamento com o livro de Paulo Lins. A autora critica Lins por ter usado os nomes dos moradores em alguns dos

4 Paratexto na orelha do livro de LINS, Paulo. Op cit. 
personagens do livro. Para ela, ele teria agido de forma impensada, năo deveria batizar seus personagens com nomes de moradores e nem ter atribuído crimes a sujeitos/personagens, antes de ter discutido com quem poderia interessar-se pelo contexto.

Em defesa aos processos judiciais, por ter nomeado os personagens com nomes de moradores e apontado tais crimes, o cineasta Fernando Meirelles disse à jornalista Cláudia Moretz-Sohn:

“[...] a gente nâo inventou aquela história. É como um espelho: a culpa náo é do reflexo, é da realidade que está sendo refletida". Paulo Lins também se posicionou em defesa do filme, ressaltando que náo ocorreu um aumento do estigma em relaçấo aos moradores da comunidade Cidade de Deus, pois esse processo "[...] năo irá ultrapassar ao que já existe. Todo favelado já é estigmatizado. E complementa: "Omitir o lado ruim é mostrar uma realidade falsa. Mostrei o que eu vivi. Eu passei por tudo aquilo" (MORETZ-SOHN apud MOTTA, 2002, grifos do autor, náo paginado).

Paulo Lins esclarece, também, que a obra náo é uma autobiografia, mas há, de certa forma, a representaçáo da sua vida quando narra, nas primeiras páginas, o personagem Busca-Pé, sinalizando as condiçôes precárias que o cercavam: “Era infeliz e nâo sabia". Diz, ainda, o autor que o romance conta a história do Conjunto Habitacional Cidade de Deus, mas apresenta o relato de um olhar de dentro, de alguém que viveu a favela e toda a sua desventura.

Outro posicionamento crítico quanto à obra de Lins foi do ex-morador do conjunto habitacional, o rapper brasileiro MV Bill5. O rapper se manifestou como porta-voz da Cidade de Deus, em um texto escrito à revista Epoca, em 2003, com o título: "A bomba vai explodir?" (MV BILL, 2003). No texto, o músico condenou Paulo Lins e os produtores do filme, dizendo que, ao invés de construírem algo para ajudar a modificar a postura social em relaçáo aos moradores do conjunto, acabaram reforçando estereótipos, em que morador aparece como "portador" de risco e ameaça social. Ademais, o rapper reclamou, ainda, que aos moradores nada restou de bom, năo receberam nenhum apoio humano, moral e social; o cantor declarou: "[...] estereotiparam nossa gente e nâo deram nada em troca para essas pessoas. Pior, estereotiparam como ficçăo e venderam como verdade (2003, sem paginaçăo) ".

Em seguida, Paulo Lins defende-se dos comentários depreciativos feitos pelo rapper em um texto denominado "Carta aberta", recolhido no site Viva Favela. O autor ressalta que năo houve, no livro ou filme, a intençăo de seguir fielmente a história da disputa das quadrilhas pelo domínio do tráfico de drogas no conjunto, visto que, se o fizesse, a obra tornar-se-ia documentário ou História (ciência), respectivamente.

Beatriz Resende, em seu livro Contemporâneos: expressōes da literatura brasileira no século XXI, no qual se dedica a pesquisar a produçăo literária da virada do século XX para o XXI, relata que a obra pioneira de Paulo Lins apresenta dificuldades à crítica

$5 \quad$ MV Bill é autor do livro Falcâo: meninos do tráfico (2006), expressâo da mesma temática do romance de Lins. O livro foi elogiado por Alba Zaluar e adaptado para a TV Globo, em forma de documentário. Vale lembrar que muitos outros livros surgiram após a obra escrita por Lins, referindo-se às mesmas temáticas de Cidade de Deus. 
literária, primeiro por ter sido apoiada e enaltecida por um dos nossos mais importantes críticos, Roberto Schwarz. Segundo, por se tratar de uma obra "[...] cuja origem está na proximidade entre autor e narrador" (2008, p. 35). Assim, o romance está muito ligado ao real, porém, o mais instigante, ressalta a autora, é o inusitado olhar de dentro.

Paulo Lins, ao pôr em cena a cultura desse espaço da zona sul do Rio de Janeiro, assumiu uma nova dicçăo, a dos que, vindos dos espaços da exclusăo, usam sua própria voz em vez da voz dos tradicionais mediadores, os intelectuais, que até recentemente por eles falavam, e marcou o início de uma nova leva de representaçóes da cidade na literatura, fora dela (no cinema, na televisăo, no teatro) ou no tênue limite dos textos depoimentos (2008, p. 36).

Sobre o contexto violento que nos é apresentado em Cidade de Deus, Beatriz Resende avalia: "[...] talvez no romance de Lins estejam as cenas mais violentas de nossa literatura" (2008 p. 36). A autora argumenta também que o fato de Paulo Lins ser ex-morador do bairro periférico faz com que o objeto de seu romance se transforme no autor: "[...] personagem, ator, agente que se situa naquele mesmo espaço físico, arquitetônico e simbólico de exclusăo de que fala" (p. 36). Essa nova maneira de fazer literatura, dispensando mediaçôes tradicionais para a construçâo de narrativas, faz surgir, segundo Resende, novas subjetividades e evidencia o que chama de sentido de presentificaçâo, de urgência, uma das mais fortes características da produçâo literária da atualidade ${ }^{6}$.

\section{A CONSTRUÇÃO LITERÁRIA: PRIVILÉGIO PERTENCENTE A UMA DETERMINADA CLASSE}

Ao refletirmos acerca das polêmicas, críticas e elogios em torno do livro Cidade de Deus, evidenciamos que tanto o grau de "realismo" do romance impactou intelectuais, jornalistas e artistas como o status social do autor. O que parece é que a produçâo literária brasileira nâo pertence a todos, mas sim a uma classe econômico-social específica. Diante disso, nos questionamos, afinal, quem săo os escritores que podem publicar e alcançar prestígio no campo literário brasileiro? Qual o perfil dos escritores que participam ativamente nos espaços de produçăo do conhecimento?

Sem muitas delongas, ao analisarmos rapidamente a história, podemos responder que as manifestaçôes literárias sâo privilégios de um grupo social formado, em sua maioria, por homens brancos e pertencentes à classe econômico-social média e alta. Aos homens negros e marginalizados pouco espaço, ou quase nada, foi dado a oportunidade de falar nas esferas literárias.

6 Após o sucesso e visibilidade, alcançado por Paulo Lins, muitos outros escritores surgiram e se destacaram, também, por retratar com intensidade o subúrbio urbano, o crime organizado, a violência e a pobreza a que sobrevivem cidadāos nas favelas brasileiras. Como exemplo, podemos citar o romancista, contista, poeta, Reginaldo Ferreira da Silva, conhecido pelo nome artístico, Ferréz. O autor costuma representar, em suas obras, a chamada "literatura marginal", visto que se desenvolve na periferia das grandes metrópoles e trata de temas relacionados a esse universo. Ferréz publicou diversos livros, entre eles: Fortaleza da Desilusāo (1997), Capâo Pecado (2001), Amanhecer Esmeralda (2005), Ninguém E Inocente em Sáo Paulo (2006), Deus foi almoçar (2012) e Os ricos também morrem (2015). Conforme estudos feitos sobre suas obras, trata-se de permanência de um espaço periférico urbano específico, permeado por mortes e episódios violentos. 
Conforme Eduardo de Assis Duarte, em seu texto intitulado Entre Orfeu e Exu, a afrodescendência toma a palavra (2014), nem sempre o negro pode falar, expressar seu ser e existir negros em verso ou prosa:

Sobretudo no passado: Falar de sua condiçáo de escravizado, ou de homem livre na sociedade escravocrata, levantar sua voz contra a barbárie do cativeiro; ou, já no século $\mathrm{XX}$, enquanto sujeito dolorosamente integrado ao regime do trabalho assalariado; ou excluído e submetido às amarras do preconceito, com suas mordaças. Apesar de tudo, muitos falaram, escreveram, publicaram. E náo só no Brasil; năo só nos países que receberam corpos prisioneiros e mentes "cheinhas de inteligência", como podemos ler no "Navio Negreiro", de Solano Trindade. Viradas as páginas dos séculos, continuam a falar, escrever, publicar. Ao percorrermos os arquivos da literatura brasileira canônica - e seus suplementos -, encontramos 0 negro náo só como raro tema da escrita do branco, mas como voz/vozes voltadas para a expressáo de seu ser e existir. Mesmo quando fazem do branco o objeto de sua fala (DUARTE, 2014, p. 13).

E acrescenta:

Nogesto ousado da construçáo literária, os afro-brasileiros nunca foram vozisolada. Se tivemos, há século e meio atrás, o "Orfeu de Carapinha", Luiz Gama a assumir sua afrodescendência e invocar a "musa de azeviche", ou a fala corajosa de Maria Firmina dos Reis - a narrar o drama de seus irmáos de cor em pleno Maranháo senhorial -, vozes outras já se inscreviam em papel impresso mundo afora para iniciar uma tradiçấo que chega aos dias de hoje. 0 veio documental presente em Úrsula (1859), e mal disfarçado por entre as franjas da ficçáo romântica, estava já presente nos versos de Phillis Wheatley, que, em 1773, tornou- se a primeira descendente de africanos a publicar poesia em língua inglesa, conforme ensinam seus estudiosos, entre eles Henry Louis Gates Jr. Estava também nos escritos memorialísticos de Olaudah Equiano, publicados em 1789, no alvorecer da revoluçáo liberal-burguesa; na autobiografia de Frederick Douglass, editada em 1845 e razăo de sua fuga para a Inglaterra, até que pudesse comprar a alforria e voltar aos Estados Unidos como orador e militante abolicionista; e estava ainda na narrativa de Mahommah Gardo Baquaqua, africano traficado para o Brasil em 1844 e batizado José da Costa, que, após escapar cinematograficamente em Nova Iorque, publica sua história em inglês, 10 anos mais tarde. Os versos e enredos dos precursores explicitam o lento processo de superaçáo da condiçấo desumana a que estavam submetidos justamente pelos povos que proclamavam sua pretensa selvageria inata (p.13).

De acordo com o autor, aos negros foi dado pouco espaço para falar e, quando falaram, na maioria das vezes, alguém falou por eles. Os elementos que construíram suas trajetórias, quase sempre, săo marcados por conquistas e superaçăo das injustiças e desumanidades. Também as dificuldades estavam em dominar códigos linguísticos estrangeiros, impostos pelo homem branco dominador, a fim de manifestar sua cultura.

Duarte menciona também que, ao investigar os manuais de literatura brasileira, perceberemos a quase ausência de literatura afrodescendente, o que contribui para sua năo institucionalizaçăo no cânone. Quando săo citados alguns nomes de 
escritores afro-brasileiros, descreve o autor: "[...] prevalece um olhar formalista propenso a isolar o texto da situaçáo histórica e social que envolve a sua produçáo e, até mesmo, a tendência em considerar tais escritores como alienados quanto à condiçâo de descendentes de africanos" (2014, p. 17). Além do pouco espaço propiciado aos escritores afro-brasileiros, muitas vezes, estăo sobre qualificaçôes negativas e săo colocados em uma condiçăo de alienaçăo frente à situaçăo de sujeitos oriundos de uma circunstância escravagista.

Com a forte dominaçâo branca sobre aqueles que vivem em locais nâo valorizados socialmente, falar e ser ouvido năo é um direito de todos, assim, săo os negros que mais encontram dificuldade. Isso porque, mesmo aqueles que ascenderam socialmente nâo estăo isentos dos efeitos da opressâo racista, pois, como disse Liv Rebecca Sovik: "[...] a branquitude é atributo de quem ocupa lugar social no alto da pirâmide, é uma prática social e o exercício de uma funçâo que reforça e reproduz instituiçóes, é um lugar de fala para o qual uma certa aparência é condiçăo suficiente" (2009, p. 50).

É certo que, em decorrência das transformaçōes do contexto brasileiro, na década de 1960 e nas seguintes ocorreram alguns avanços nas articulaçóes e nos diálogos entre homens e mulheres negras, entretanto, mesmo que muito ainda precise ser feito, podemos afirmar que novas vozes estăo se juntando ao coro da afrodescendência. Diante disso, a literatura tem sido um instrumento de denúncia e de resistência de pessoas, antes distante de um sistema sociocultural.

Com a tomada de consciência de alguns afrodescendentes através da quebra de paradigmas sociais e culturais, eles tornam-se autores de suas histórias, rompem as mediaçōes nas suas construçôes de narrativas. "Eles travam lutas para obter espaço e visibilidade, também lutam contra as suas representaçôes já fixadas na tradiçăo literária e, ao mesmo tempo, reafirmar a legitimidade de sua própria construçáo [...]" (DALCASTAGNÉ, 2007, p. 18).

Dessa maneira, precisam lutar também contra o racismo disseminado nas mídias, em especial, nos programas televisivos. A televisăo, um dos principais meios midiáticos, tem representado os negros de forma estereotipada e deformada, sem a devida vinculaçâo com a construçáo de uma imagem positiva. É na televisáo, quase sempre, que os negros veem negada sua história.

Segundo Joel Zito Araújo (2000), é durante o carnaval que a televisăo brasileira transmite para o mundo os desfiles carnavalescos nos sambódromos das metrópoles Rio de Janeiro e Săo Paulo. Dessa maneira, por cinco dias, acompanhamos pela rede televisiva um "espetáculo da miscigenaçâo" e observamos a participaçáo de homens e mulheres afrodescendentes em nossa sociedade. Mas é nas telenovelas brasileiras e nos comerciais, durante o ano inteiro, que acompanhamos a confirmaçăo da vitória simbólica da ideologia do branqueamento e da "democracia racial brasileira":

Aí percebemos as consequências do desinteresse histórico da elite brasileira em formar um mercado consumidor amplo, em seu próprio país, e da preferência pela imigração da măo de obra europeia no período final da escravidăo, em detrimento do trabalho negro. Empresários, publicitários e produtores de tevê, como norma, optam pelo grupo racial branco, nos processos de escolha dos modelos publicitários, na estética da propaganda e até mesmo nos critérios de patrocínio ou apoio a projetos culturais (ARAÚJO, 2000, p. 39). 
A falta de incentivos culturais aos programas de televisăo voltados para a populaçăo afro-brasileira justifica-se pela descrença de que haverá retorno comercial. O patrocinador năo os percebe como uma força econômica. Na lógica dessa maioria, preto é igual a pobre, que é igual a consumo de subsistência. "Os interditos do tabu racial, que rejeitam a negritude e promovem a branquitude, com seus modelos de estética e bom gosto calcados nas construçóes do mundo branco" (ARAÚJO, 2000, p. 39).

Nesse contexto excludente, a produçâo literária também năo é assumida pelos negros devido a náo se sentirem capazes de participar desse espaço que a eles, veladamente, é negado. Sobre essa problemática, Regina Dalcastagnè afirma:

Aqueles que estăo objetivamente excluídos do universo do fazer literário, pelo domínio precário de determinadas formas de expressáo, acreditam que seriam também incapazes de produzir literatura. No entanto, eles săo incapazes de produzir literatura exatamente porque năo a produzem: isto é, porque a definiçăo de literatura exclui suas formas de expressăo (2012, p. 20).

Escrever sobre si e seu mundo, num território que lhe é estrangeiro, significa uma atitude ousada e a quebra de paradigmas. Ora, o campo literário sempre pertenceu a escritores intelectuais brancos, críticos, educadores de classes sociais privilegiadas. Eles instauram seus gostos, interesses e preferências, ditam o que deve ou náo ser lido, o que precisa ou năo ser preservado. Lembremo-nos de que, para Compagnon, “[...] todo julgamento de valor repousa num atestado de exclusăo. Dizer que um texto é literário subentende, sempre, que o outro nâo é" (1999, p. 33-34). E năo esqueçamos do julgamento de valor, imposto sobre as obras, pois o que é "bom" ou que é "melhor" está ligado a questôes literárias, como a exclusâo e a canonizaçấo. Nessa perspectiva de discurso, há exigências, regras e limitaçōes que "determinam quem pode falar (de fato e de direito), a quem e como" (BOURDIEU, 2013, p. 149).

Em regra, portanto, a palavra năo pode ser tomada por qualquer um, nem todos podem falar sobre qualquer coisa em qualquer circunstância. Segundo o filósofo Michel Foucault, em seu livro A ordem do discurso: "[...] todo discurso é feito a partir de certo lugar, o que implica tomarmos consciência desses lugares e dos modos de produçáo dos saberes" (2004, p. 9).

O filósofo francês alerta sobre a importância de entendermos o discurso como uma violência, como uma prática que impomos às coisas e ao mundo. Ademais, toda a produçăo de discurso, independentemente da sociedade a que nos referirmos, é sempre, segundo o autor: "controlada, selecionada, organizada e redistribuída por certo número de procedimentos que têm por funçáo conjurar seus poderes e perigos, dominar seu acontecimento aleatório, esquivar sua pesada e temível materialidade" (2004, p. 9). Assim, Foucault, ao afirmar o controle do discurso, denuncia que falar, ser ouvido e aceito por aquele que ouve năo é direito de todas as pessoas, uma vez que existem restriçôes e exigências, portanto, é necessário pertencer a determinado local e preencher certos requisitos sociais.

Nessa mesma perspectiva, Pierre Bourdieu acrescenta que o ato de falar vai além do que pensamos, que a língua serve para comunicar, interagir e adquirir conhecimento (2013, p. 148). Para Bourdieu, aquele que fala anseia para além de ser compreendido, visto que deseja ser também respeitado, obedecido e reconhecido pelo receptor: "[...] 
daí a definiçăo completa da competência como direito à palavra, à linguagem legítima como linguagem autorizada, de autoridade" (2013, p. 148). A competência, para o autor, significa ser aceito, ouvido e respeitado pelo receptor. Ele problematiza ainda que: “[...] dentre as censuras mais radicais, seguras e escondidas, estăo as que excluem certos indivíduos da comunicaçăo (nâo os convidando para os lugares de onde se fala com autoridade, ou colocando-os em lugares sem palavras) [...]" (2013, p. 149).

A questâo que Bourdieu levanta é que náo se trata somente da possibilidade de poder se expressar na sociedade, mas de se poder falar de um local reconhecido socialmente e de possibilitar alguma imposiçăo àquele que ouve. E, além de nâo nos comunicarmos com qualquer um, também nâo é de qualquer sujeito que se pode "tomar" a palavra, que se pode falar e ser ouvido por alguém que também está em um lugar de reconhecimento. “O discurso supóe um emissor legítimo dirigindo-se a um destinatário legítimo, reconhecido e reconhecedor" (BOURDIEU, 2013, p. 149).

O uso da linguagem como discurso depende da posiçáo social daquele que fala e do local onde a linguagem representa a autoridade, pois năo săo as palavras que obtêm poder, mas sim é a autoridade que reveste as palavras de fora. De acordo com Bourdieu (2013, p. 150):

[...] a verdade da relaçăo de comunicaçăo nunca está inteiramente no discurso nem nas relaçóes de comunicaçăo. Uma verdadeira ciência do discurso deve buscar essa verdade no discurso, mas também fora dele, nas condiçóes sociais de produçáo e reproduçăo de produtos, por exemplo, para que a linguagem de importância do filósofo seja recebida, é preciso que esteja reunida as condiçōes que ela seja capaz de obter a importância que a elas se concede.

Portanto, é fundamental considerar de onde vem o discurso e em que circunstâncias históricas e sociais efetivou-se o ato do discurso e a quem está se referindo (BOURDIEU, 2013). Nessa esteira, vale citar Roberto Reis, que ao falar sobre Cânon, em ensaio publicado pela primeira vez em 1992, no livro Palavras da crítica, organizado por José Luís Jobim, afirma:

A escrita e o saber, na cultura ocidental, estiveram via de regra de máos dadas com o poder e funcionaram como forma de dominaçăo. Todo o saber é produzido a partir de determinadas condiçóes históricas e ideológicas que constituem o solo do qual esse saber emerge. Toda interpretaçăo é feita a partir de uma dada posiçấo social, de classe, institucional. É muito difícil que um saber esteja desvinculado do poder. Com isso deduzimos que os textos năo podem ser dissociados de uma certa configuraçăo ideológica, na proporçáo em que o que é dito depende de quem fala no texto e de sua inscriçáo social e histórica. O que equivale a afirmar que todo texto parece estar intimamente sobredeterminado por uma instância de autoridade (REIS apud JOBIM, 1992, p. 3).

Diante disso, é possível afirmar que é por trás de noçōes como linguagem, cultura e literatura que se escondem as marcas de poder. A escrita sempre foi uma forma de poder, haja vista que na antiguidade o escriba e o sacerdote eram poderosos ou prestavam serviço aos homens do poder. "Da mesma forma que, nas sociedades pós-industriais, o monopólio da informaçâo através dos meios de comunicaçâo de massa desempenha um papel fundamental no que tange à dominaçăo social [...]" (REIS, 1992, p. 2). 
Como já refletido acima, ocorreram algumas mudanças significativas em nossa sociedade e é perceptível a mobilizaçâo de determinados grupos - refiro-me aos negros, isto é, àqueles a que mais foram negados espaços de fala e que foram colocados, como afirmou Bourdieu, onde năo existem palavras -, em busca de seus direitos e de espaços de fala. Atualmente, acontecem eventos nacionais e internacionais em defesa das culturas de matriz africana e de combate ao racismo. Apoderaram-se de seu discurso, passaram a contestar, lutando contra a condiçâo subalterna, entretanto, muito precisa ser feito e conquistado, uma vez que o poder de fala ainda é restrito, já que poucos têm acesso ao espaço no qual há autoridade para falar e para ser ouvido.

Sáo os homens os que têm mais oportunidade de falar e de serem ouvidos, em comparaçấo com as mulheres. As mulheres brancas, por conta de sua localizaçấo social, percebem seu próprio gênero diferentemente das mulheres nâo brancas. As cobranças sâo sempre maiores em relaçăo aos indivíduos pertencentes a grupos historicamente discriminados. Assim sendo, é fundamental, segundo Djamila Ribeiro (2017), analisar năo somente um grupo de pessoas, mas sim verificar as várias condiçôes que resultam em desigualdades e hierarquias, que se "servem" de grupos que vivem à margem, locais desprotegidos onde impera todo e qualquer tipo de violência, bem como desumanidade.

Djamila Ribeiro (2017), ao debater os principais conceitos do feminismo negro por meio de um olhar político e de análise interseccional, nomeando as opressóes de raça, gênero e classe, em seu livro 0 que é: o lugar de fala, relata a importância de se rever as experiências dos que se encontram em locais confortáveis de fala, os que estăo:

[...] localizados socialmente de forma hierarquizada e năo humanizada faz com que as produçôes intelectuais, saberes e vozes sejam tratadas de modo igualmente subalternizado, além das condiçóes sociais os manterem num lugar silenciado estruturalmente. Isso, de forma alguma, significa que esses grupos năo criam ferramentas para enfrentar esses silêncios institucionais, ao contrário, existem várias formas de organizaçōes políticas, culturais e intelectuais [...] (2017, p. 63).

No entanto, para a autora, muitas mudanças săo necessárias a fim de que possamos mudar a realidade em que vivemos, pois, nos locais em que é produzido o conhecimento, nos quais há autorizaçáo para falar e discutir, o número de mulheres e homens negros é irrisório. Diante disso, um exemplo, diz ela, acontece em espaços como as universidades, nos quais, na maioria das vezes, alunos nâo têm acesso a autores negros nem a mediaçōes de conteúdos com pessoas negras. $O$ fato é que, ainda hoje, em pleno século XXI, poucos săo os de origem afrodescendente que circulam por instituiçôes que produzem discursos e que fazem parte de locais de prestígio em nossa sociedade.

O problema é que enquanto os grupos marginalizados (pensando de modo amplo, todos os que vivenciam qualquer tipo de discriminaçáo social e que sejam definidos por sexo, etnia, cor, orientaçăo sexual e condiçâo física) receberem valoraçăo negativa da cultura dominante e, consequentemente, năo tiverem acesso ao mercado de trabalho (ao trabalho reconhecido socialmente: o que gera status social-econômico), à universidade, de forma justa, năo teremos produçôes e epistemologias desses grupos nesses espaços. Assim, o "[...] perigo é de se constituir o outro e o subalterno apenas como objeto de conhecimento por parte dos intelectuais que almejam meramente 
falar pelo outro, conforme alerta Gayatri Chakravosty Spivak em seu clássico ensaio Pode o subalterno falar? (2010, p. 12).

Participar ativamente nos espaços de produçăo de sentido da sociedade é possibilitar, aos seres humanos, o reconhecimento do poder de existir, pois falar năo se restringe ao ato de emitir palavras, mas de existir. Falar implica, necessariamente, que o receptor ouça e reconheça quem fala, mas, para isso, diz Spivak (2010), é necessário estar no espaço socialmente reconhecido, assim como nos apontam Bourdieu e Foucault.

Spivak (2010) postula que o subalterno năo pode falar. Subalterno é aquele, conforme Gramsci denominou, cuja voz nâo pode ser ouvida pelo fato de pertencer às "camadas mais baixas da sociedade" e, portanto, suas falas săo, sistematicamente, silenciadas dentro dos meios de representaçôes existentes, sejam eles legais, econômicos, políticos ou acadêmicos. Para a intelectual, é necessário que ocorram mudanças, pois o subalterno deve estar à frente do discurso e năo ser representado por um outro. Isso porque qualquer tentativa de falar em nome do subalterno acaba por distorcer sua posiçâo e, novamente, negar-lhe a oportunidade de falar por si próprio. Spivak também problematiza que:

[...] o lugar incômodo e cumplicidade do intelectual que julga poder falar pelo outro e, por meio dele, construir um discurso de resistência. Agir dessa forma, é reproduzir as estruturas de poder e opressăo, mantendo o subalterno silenciado, sem lhe oferecer uma posiçăo, um espaço de onde possa falar e, principalmente, no que possa ser ouvido [...] (SPIVAK, 2010, p. 3).

Nas afirmaçôes da autora, fica evidente a urgência de se oportunizar espaços de fala aos sem voz, ao invés de continuar a prover os que falam pelos subalternos. Deve-se orientar as pessoas a enfrentar atos de autoridades e ir contra o processo de subalternidade.

Historicamente, as classes populares possuem menor capacidade de acesso a todos os campos de produçăo discursiva, sâo sub-representados na política, no ambiente acadêmico e entre tantos outros campos da sociedade que produzem conhecimento. No campo da narrativa brasileira, conforme a pesquisa realizada pela professora Regina Dalcastagnè (2008), cujo objetivo é traçar o perfil dos escritores e dos personagens da literatura brasileira contemporânea, sâo os brancos que predominam nos enredos. Assim, quando os negros sâo representados, na maioria das vezes, nâo sâo protagonistas e nem narradores e geralmente aparecem em posiçăo secundária no texto, ou seja, numa posiçāo subalternizada no enredo.

Todavia, a situaçâo é ainda mais grave em relaçăo aos escritores, afirma a autora. “De maneira um tanto simplista e cometendo alguma (mas nâo muita) injustiça, é possível descrever nossa literatura como sendo a classe média olhando para a classe média" (2008, p. 79, grifo nosso). Obviamente, nâo quer dizer que, segundo a autora: "[...] náo possa haver aí boa literatura, como de fato há - mas com uma notável perspectiva" (DALCASTAGNE, 2008, p. 79, grifo nosso).

Ressalta a escritora:

A literatura contemporânea reflete, nas suas ausências, talvez ainda mais do que naquilo que expressa, algumas das características centrais da sociedade brasileira. É o caso da populaçâo negra, que séculos de racismo estrutural afastam 
dos espaços de poder e de produçăo de discurso. Na literatura, năo é diferente. Sáo poucos os autores negros e poucas, também, as personagens - uma ampla pesquisa com romances das principais editoras do País publicados nos últimos 15 anos identificou quase $80 \%$ de personagens brancas, proporçăo que aumenta quando se isolam protagonistas ou narradores. Isto sugere uma outra ausência, desta vez temática, em nossa literatura: o racismo. Se é possível encontrar, aqui e ali, a reproduçâo paródica do discurso racista, com intençăo crítica, ficam de fora a opressâo cotidiana das populaçôes negras e as barreiras que a discriminaçăo impóe às suas trajetórias de vida. O mito, persistente, da'democracia racial' elimina tais questóes dos discursos públicos, incluindo aí o do romance (DALCASTAGNĖ, 2008, p. 87).

É evidente que a exclusāo de determinados grupos nâo é encontrada apenas no campo literário, como já discutido acima. As classes populares, as mulheres, os negros possuem maiores dificuldades para acessar todas as esferas de produçáo discursiva: estâo sub-representados no parlamento (e na política como um todo), assim como na mídia e no ambiente acadêmico. Para melhor entendimento basta analisar os índices apontados no relatório “Desigualdades Sociais por Cor ou Raça no Brasil”, publicado em 2019. Infelizmente, os negros ainda sâo proporcionalmente sub-representados, seja no campo da educaçăo ou em qualquer outro setor da sociedade.

Figura 23: IBGE. ${ }^{7}$

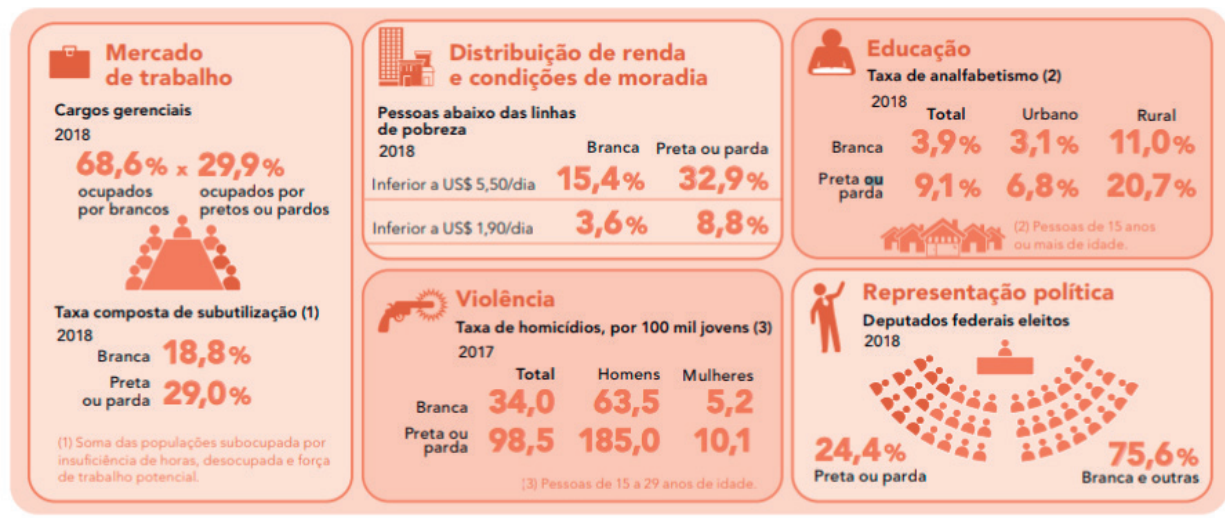

Fonte: IBGE, Diretoria de Pesquisas, Coordenação de População e Indicadores Sociais.

Diante das discussóes, concluímos que o fazer literário năo pertence a todos, mas sim às pessoas que possuem determinadas características, que se encontram em lugares de reconhecimento social. Dessa feita, é inquestionável que săo os brancos os que mais têm acesso e que mais publicam e, consequentemente, săo os mais lidos. A maioria da populaçăo empobrecida, sem escolarizaçăo ${ }^{8}$ e excluída (negros e brancos), está

7 Disponível em: https://www.ibge.gov.br/estatisticas/sociais/populacao/25844-desigualdades-sociaispor-cor-ou-raca.html?=\&t=publicacoes. Acesso em: set. 2020.

8 Infelizmente, em meio a muitas promessas, voltadas para o desenvolvimento educacional, o Brasil, segundo dados divulgados pelo Instituto Brasileiro de Geografia e Estatística- IBGE, (2019) , “.... tem 10,1 milhóes de jovens de 14 a 29 anos que náo frequentam a escola nem concluíram o ensino médio, sendo que 7,2 milhōes deles săo pretos ou pardos". 
distante do campo literário, seja como escritor ou como leitor. Os afrodescendentes, como sabemos, estăo ainda mais distantes do universo televisivo e cinematográfico, de forma que sua atuaçăo é quase irrisória nesses meios.

\section{CONSIDERAÇÕES FINAIS}

Ao nos determos em torno do romance, de Paulo Lins, pudemos constatar, que, embora tenha alcançado reconhecimento dentro do campo cultural literário, também causou discussóes sobre a sua legitimidade, pelo fato de ter sido escrito por um homem negro, pobre e oriundo de uma localidade marginalizada, onde nâo existe reconhecimento social. Ao aprofundarmos essa questăo, desvelamos que a participaçăo dos afrodescendentes no desenvolvimento da produçâo literária brasileira é quase que inexistente, poucos foram os negros que conseguiram romper os códigos, as tradiçôes que asseguram o campo literário.

A produçăo literária, conforme discutido neste trabalho, é legado de determinadas pessoas que preenchem certos requisitos sociais, ela nunca pertenceu a todos, sempre foi tarefa de escritores intelectuais brancos, educadores de classes sociais privilegiadas. Săo eles que produzem, publicam e dizem o que é bom e deve ser lido. E, sem dúvida săo, principalmente, os afrodescendentes os que mais encontram dificuldade para transitar nesse meio de produçáo de conhecimento.

Historicamente, os pobres, negros e marginalizados săo os que possuem mais dificuldades para acessar qualquer esfera de produçâo discursiva. Assim sendo, evidenciamos que embora Paulo Lins tenha sido apoiado por um importante intelectual, crítico e escritor, ele náo passaria imune devido à sua origem e à sua cor. Talvez, as polêmicas e as críticas levantadas contra Paulo Lins dâo-se muito mais por ele ser quem é. 


\section{REFERÊNCIAS}

ARAÚJO, Joel Zito. A negaçăo do Brasil: o negro na telenovela brasileira. Săo Paulo: Senac, 2000.

BILL, MV. A bomba vai explodir? 2003. Disponível em: http://revistaepoca.globo.com/ Revista/Epoca/0,EDR55184-6011,00.html. Acesso em: 23 nov. 2019.

BOURDIEU, Pierre. A sociologia de Pierre Bourdieu. Renato Ortiz (Org). Săo Paulo: Olho d'Água, 2013.

COMPAGNON, Antoine. 0 demônio da teoria: literatura e senso comum. Traduçâo de Cleonice Paes Barreto Mouráo. Belo Horizonte: UFMG, 1999.

DALCASTAGNÈ Regina (Org.). Ver e imaginar o outro: alteridade, desigualdade, violência na literatura brasileira contemporânea. Vinhedos: Ed. Horizonte, 2008.

DALCASTAGNÈ. Regina. Literatura e exclusăo. In: Eble, Laeticia Jensen; Dalcastagnè, Regina. Porto Alegre, RS: Zouk, 2017.

DALCASTAGNE, Regina. A auto-representaçăo de grupos marginalizados: tensōes e estratégias na narrativa contemporânea. Porto Alegre: Letras de Hoje, v. 42, n. 4, p. 1831, dezembro 2007. Disponível em: f file://C:/Users/Acer/Downloads/4110-Texto\%20 do\%20artigo-13067-1-10-20080915\%20(1).pdf. Acesso em: 19 dez. 2019.

DALCASTAGNE, Regina. Um território contestado: literatura brasileira contemporânea e as novas vozes sociais. 2012 Disponível em: file://C:/Users/Acer/Desktop/Artigos\%20e\% 20Livros/Dalcastagne\%20lit\%20bras\%20contemp\%20e\%20as\%20novas\%20vozes\%20 sociais.pdf. 2012. Acesso em: 11 nov. 2019.

DUARTE, Eduardo Assis. Entre Sertăo e Subúrbio: Guimarăes Rosa e Paulo Lins. O Eixo e a Roda. Revista de Literatura Brasileira, [S. I.], v. 7, p. 119-125, maio 2001. Disponível em: http://www.periodicos.letras.ufmg.br/index.php/o_eixo_ea_roda/article/view/3101. Acesso em: 25 nov. 2019.

DUARTE, Eduardo de Assis. Entre Orfeu e Exu, a afrodescendência toma a palavra. 2011a. In: Literatura e afrodescendência no Brasil: antologia crítica. 2. ed. Belo Horizonte: Editora UFMG; Brasília: SEPPIR, 2014, v. 1, Precursores, p. 13-48. Disponível em: file://C:/Users/Acer/Desktop/Artigos\%20e\%20Livros/Eduardo\%20ASSIS.pdf. Acesso em: 12 dez. 2020.

FOUCAULT, Michel. A ordem do discurso: aula inaugural no Collège de France, pronunciada em 2 de dezembro de 1970. Traduçāo de Laura Fraga de Almeida Sampaio. 10. ed. Săo Paulo: Loyola, 2004.

GÓIS, Antônio. Hipermasculinidade leva jovem ao mundo do crime. 2004. Disponível em: https://www1.folha.uol.com.br/fsp/brasil/fc1207200423.htm. Acesso em: 31 ago. 2020.

LINS, Paulo. Cidade de Deus. Săo Paulo: Companhia das Letras, 1997. 1. ed.

LINS, Paulo. Sem medo de ser. Revista Caros Amigos, maio 2003.

LINS, Paulo. Carta aberta. Disponível em: http://www.cinemaemcena.com.br/cinemacena/ variedades_textos.asp?cod=20. Acesso em: 01 fev. 2020. 
MORETZ-SOHN, Claudia. Entre câmeras e traficantes (entrevista com F. Meirelles em 06/08/2002). Globo.com. Disponível em: https://www.google.com/search?q=MORETZSOHN\%2C+Claudia.+Entre+c\%C3\%A2meras+e+traficantes\&oq=MORETZ-SOHN\%2C+Claudia.+Entre+c\%C3\%A2meras+e+traficantes\&aqs=chrome..69i57.1057j0j7\&sourceid=chrome\&ie=UTF-8. Acesso em: 05 jan. 2020.

PELLEGRINI, Tânia. No fio da navalha: literatura e violência no Brasil de hoje. In: DALCASTAGNÈ, Regina (Org.). Ver e imaginar o outro: alteridade, desigualdade, violência na literatura brasileira contemporânea. Vinhedos: Ed. Horizonte, 2008. p. 41-56.

PELLEGRINI, Tânia. As vozes da violência na cultura brasileira contemporânea. 2005. Disponível em: https://www.academia.edu/1303728/As_vozes_da_viol\% C3\% AAncia_ na_cultura_brasileira_contempor\%C3\%A2nea. Acesso em: 5 jan. $20 \overline{20}$.

PELLEGRINI, Tânia. No fio da navalha: literatura e violência no Brasil de hoje. In: DALCASTAGNE, Regina (Org.). Ver e imaginar o outro: alteridade, desigualdade, violência na literatura brasileira contemporânea. Vinhedos: Ed. Horizonte, 2008. p. 41-56.

REIS, Roberto. Cânon. 1992. Disponível em: https://social.stoa.usp.br/articles/0037/3007/C_NON__roberto_reis.pdf. Acesso em: 8 jan. 2020.

RESENDE, Beatriz. Contemporâneos: expressōes da literatura brasileira no século XXI. Rio de Janeiro: Casa da Palavra: Biblioteca Nacional, 2008.

RIBEIRO, Anabela Mota. Paulo Lins (Cidade de Deus). Blog, 2003. Disponível em: https:// anabelamotaribeiro.pt/paulo-lins-a-pretexto-de-cidade-de-deus-181225. Acesso em: 30 out. 2019.

RIBEIRO. Djamila. O que é lugar de fala. Belo Horizonte: Letramento, 2017.

SCHWARZ, Roberto. Sequências brasileiras. Săo Paulo: Companhia das Letras, 1999.

SCHWARZ, Roberto. Uma aventura artística incomum. Disponível em: https://www1. folha.uol.com.br/fsp/1997/9/07/mais!/24.html. Acesso em: 18 jun. 2019.

SOVIK, Liv. Aqui ninguém é branco. Rio de Janeiro: Aeroplano, 2009.

SPIVAK, Gayatri. C. Pode o subalterno falar? Trad. De Sandra Regina Almeida, Marcos Pereira Feitosa, André Pereira Feitosa. Belo Horizonte: UFMG, 2010.

ZALUAR, Alba. A máquina e revolta: as organizaçōes populares e o significado da pobreza. 2. ed. Sáo Paulo: Brasiliense, 2000. 